\title{
Protein quality in cereals and pulses
}

\section{Application of microbiological and other in vitro methods in the evaluation of rice (Oryza sativa L.), sorghum (Sorghum vulgare Pers.), barley and field beans (Vicia faba L.)}

\author{
BY J. E. FORD AND D. HEWITT \\ National Institute for Research in Dairying, Shinfield, Reading RG2 $9 A T$
}

(Received 23 June $1978-$ Accepted 28 July 1978)

\begin{abstract}
1. The Streptococcus zymogenes assay procedure was modified and used in the estimation of available methionine and relative nutritional value in rice (Oryza sativa L.), sorghum (Sorghum vulgare Pers.), barley and field beans (Vicia faba L.). The results were assessed in relation to the content of tannins and 'dyebinding lysine', and to published information on the nutritional quality of some of the test samples.

2. In grain of ten varieties of sorghum, for which other workers had reported a correlation $(r-0.82$; $P<0.0$ ) between tannin content and amino acid digestibility in chicks, the available methionine content ranged from 6.3 to $17.7 \mathrm{~g} / \mathrm{kg}$ protein (nitrogen $\times 6.25$ ) and was highly correlated with tannin content $(r-0.97 ; P<0.001)$. The content of total methionine and dye-binding lysine varied little between varieties and was not related to tannin content.

3. In nine samples of rice the availability of methionine was uniformly high, in accordance with literature values for true digestibility of the $\mathrm{N}$.

4. In field beans the presence of tannins in the seed coat was associated with a significant $(P<0.00 \mathrm{I})$ reduction in the availability of methionine. In eleven tannin-free varieties the coefficient of availability averaged 0.791 , compared with 0.685 in eleven tannin-containing varieties. The standard deviation associated with both values was 0.04 . There was no such difference between the corresponding dye-binding lysine values.

5. Thirty-three samples of barley were examined, representing fourteen varieties, four of which had been grown at several widely different latitudes in England and Sweden. There was little difference in methionine content between samples. The average availability coefficient for eighteen samples grown in England was $0.995 \pm 0.044$, and for fifteen varieties grown in Sweden it was $0.851 \pm 0.042$. The difference was not associated with any difference in tannin content, which was uniformly low. The findings contradict published evidence for marked increase in tannin content with increase in geographical latitude of cultivation, associated with decrease in digestibility of $\mathrm{N}$.
\end{abstract}

The rapid increase in world population lends urgency to the efforts of plant breeders in many countries to increase yield and nutritional quality in food grains. A serious handicap to progress in this work is the lack of reliable methods for use in the early screening of large numbers of isolates; unless the breeder has simple and appropriate tests for important nutritional characteristics he may well discard much valuable material during the early phases of the breeding programme. A particular need is for methods for protein-quality evaluation that are applicable to cereals, and that are quick and simple and more economical of test materials than animal feeding trials. Some microbiological assay techniques show considerable promise for this type of application.

The Streptococcus zymogenes assay for available methionine has been extensively tested with fish meals and several other protein-rich foodstuffs, and for these it gives values that are highly correlated with, and in general quantitatively similar to, those obtained with chick and rat growth assays (cf. Ford, 1962; Ford \& Salter, 1966; Miller et al. 1965; Carpenter \& Woodham, I974; Boyne et al. 1975). There is no comparable body of information for cereals and other low-protein foodstuffs. Papain predigestion as applied in the standard assay procedure (Boyne et al. 1975 ) is difficult and sometimes impracticable with the larger weights of test sample required, and growth responses in the assays have to be determined indirectly from measurements of acid production in the cultures. Ford (1964) 
found that results obtained in this manner were less reproducible than those for highprotein materials as calculated from turbidity measurments. A further difficulty in extending the microbiological test to cereals was the lack of precise comparative information from tests with animals. The biological assessment of protein quality is difficult in materials of low protein content, and particularly so if the protein is of poor quality and limiting in lysine, when the biological value may be strongly influenced by the level of protein in the test diet (cf. Hegsted \& Juliano, 1974).

In some food grains part of the protein may be intrinsically of low digestibility, or become indigestible during processing through interaction with polyphenols which are widely present in higher plants. This complicates the interpretation of amino acid analysis and other compositional information in terms of nutritional quality. The problem is well illustrated in sorghums, (Sorghum vulgare Pers.), which exhibit wide differences in digestibility that reflect corresponding differences in tannin content. A selection of sorghums was included in the present study. For ten of them the content of digestible amino acids had been determined in experiments with chicks, by a faecal analysis procedure (Nelson et al. 1975). Nine samples of rice (Oryza sativa L.) were also examined, for which extensive information on digestibility and nutritional quality was available, and thirty-three samples of barley.

The seed coat of coloured-flowered varieties of field beans (Vicia faba L.) is rich in condensed tannins, and several workers have reported that the inclusion of such tannincontaining beans at a high concentration in the diet of single-stomached animals may impair the nutritional quality (for references, see Martin-Tanguy et al. 1977). Therefore, seed of twenty-two bean varieties was included in the present study.

All the test materials were assayed with Strep. zymogenes for total and available methionine and for relative nutritional value (RNV). Some were also assayed for 'available' lysine by a dye-binding method, and for tannins.

\section{EXPERIMENTAL}

\section{Test materials}

Sorghum. In all, seed of nineteen varieties of hybrid sorghum was examined, representing a wide range of tannin content. Sixteen of the varieties were grown in the USA and three in Africa.

Rice. Nine samples of rice flour were obtained, from rice grown and milled in the Philippines during the period $1969-1972$ and stored at $2-4^{\circ}$ in sealed polythene bags. Information on composition and results of protein-quality tests with animals are given by Bressani et al. (197I), Eggum \& Juliano (I973) and Hegsted \& Juliano (I974).

Barley. Five samples of barley of the variety Ingrid were examined, from crops grown in Sweden at widely separate geographical latitudes and harvested at the same stage of maturity. Tests with laying hens had indicated a progressive decrease in protein digestibility with increase in latitude, related to differences in tannin content (Gohl \& Thomke, 1977). Eighteen samples were obtained from the National Institute of Agricultural Botany at Cambridge, representing seed of barley varieties Sundance, Julia and Magnum, each grown at six trial centres in England at latitudes ranging from $50^{\circ} 30^{\prime} \mathrm{N}$ (South Devon) to $55^{\circ} 30^{\prime} \mathrm{N}$ (Northumberland). A further ten samples were obtained from the Swedish Seed Association at Svalöv, representing seed of the varieties Aramir, Gull, Kornett, Lofa, Mazurka, Senat, Särla, Hiproly, Risö 1508 and Glacier, harvested in Sweden in 1976.

Field beans. Seed of twenty-two varieties of field beans was obtained from the Plant Breeding Institute at Cambridge, eleven white-flowered and eleven coloured. With two of the varieties, Triple White (white) and Beagle (coloured), some of the seeds were broken by passage through a food mincer and the testa separated from the cotyledons by winnowing. 


\section{Analytical methods}

Milling of the samples. The rice samples were received as flours passing a 60 mesh sieve. The remaining samples consisted of whole seeds and they were ground in a hammer mill to pass a 40 mesh sieve. A portion (approximately $8 \mathrm{~g}$ ) of each was further milled to pass an 80 mesh sieve by treatment for $30 \mathrm{~min}$ in a reciprocating ball mill.

Strep. zymogenes assays. The general procedure was that described by Boyne et al. (1975), but different methods of enzymic predigestion were employed, as follows.

Digestion with papain. A weight of sample calculated to contain $12.5 \mathrm{mg}$ nitrogen was suspended in $10 \mathrm{ml}$ citrate-cyanide buffer (Boyne et al. 1975) in a screw-stoppered bottle. The $\mathrm{pH}$ value was adjusted to 7.2 and $\mathrm{I} \mathrm{ml}$ crude papain (British Drug Houses Ltd, Poole) solution ( $40 \mathrm{~g} / \mathrm{l}$ in the citrate-cyanide buffer) was added. The mixture was incubated at $56^{\circ}$ for $3 \mathrm{~h}$ in an 'end-over-end' shaker (Ford, 1964) and then adjusted to $\mathrm{pH} 7 \cdot 2$ and diluted with water to contain 5-10 $\mu \mathrm{g}$ methionine $/ \mathrm{ml}$. With cereals a suitable final volume was $200 \mathrm{ml}$ and with field beans $100 \mathrm{ml}$.

Digestion with pronase. The test sample (12.5 $\mathrm{mg} \mathrm{N}$ ) was suspended in $10 \mathrm{ml}$ sodium $\beta$-glycerophosphate solution $(20 \mathrm{~g} / \mathrm{l})$. The $\mathrm{pH}$ value was adjusted to 8.0 and $\mathrm{I} \mathrm{ml}$ pronase (B grade; Calbiochem Ltd, Hereford) (ro g/l in the glycerophosphate solution) was added. The mixture was incubated at $48^{\circ}$ for $3 \mathrm{~h}$ and then diluted, as described previously.

Digestion with pepsin. The test sample $(25 \mathrm{mg} \mathrm{N})$ was suspended in $25 \mathrm{ml}$ water and heated in flowing steam for $30 \mathrm{~min}$. After cooling, the resulting paste was brought to $\mathrm{pH} \mathrm{r} .8$ by slow addition of I M-hydrochloric acid, and I $\mathrm{ml}$ crystalline pepsin (Koch-Light Laboratories $\mathrm{Ltd}$, Colnbrook) solution ( $\mathrm{I} 0 \mathrm{~g} / 1$ in $0.033 \mathrm{M}-\mathrm{HCl}$ ) was added. The mixture was incubated at $48^{\circ}$ for $3 \mathrm{~h}$ in an 'end-over-end' shaker, adjusted to $\mathrm{pH} 7 \cdot 2$, and diluted to contain $5-10 \mu \mathrm{g}$ methionine/ml.

Enzyme 'blanks' were included in all the assays.

The inoculum culture was maintained by daily transfer in basal medium diluted to single strength and supplemented with $\mathrm{I} \cdot 5 \mathrm{~g}$ casein and $\mathrm{I} 50 \mathrm{mg}$ sodium glutamate/1 (Ford, 1964). For assays of total methionine the samples were hydrolysed in $100 \mathrm{ml}$ conical flasks, as follows. To samples of cereal containing $12.5 \mathrm{mg} \mathrm{N}$ were added $20 \mathrm{ml} 3 \mathrm{M}-\mathrm{HCl}$. The flasks were covered and heated in a steam autoclave for $16 \mathrm{~h}$ at $115^{\circ}$, cooled, and neutralized by slow addition of $\mathrm{I} \mathrm{M}$-sodium hydroxide with stirring. The hydrolysates were then diluted to $200 \mathrm{ml}$ and filtered, and assayed against a standard solution containing Io $\mu \mathrm{g} \mathrm{L}$-methionine/ $\mathrm{ml}$ in $0.3 \mathrm{M}$-sodium chloride solution. Growth responses in the test cultures were assessed by titration against $0^{\circ} \mathrm{I} \mathrm{M}-\mathrm{NaOH}$ to $\mathrm{pH} 8 \cdot 2$, with a Radiometer type TTTIC titrator (Radiometer A/S, Copenhagen).

Dye-binding measurements. Dye-binding capacity for Acid Orange I 2, and dye-binding lysine, were measured with a Pro-Meter Mk 2 (A/S Foss Electric, Hilleröd) as described by Hurrell \& Carpenter (1975, I976).

Measurement of tannins. The tannin content of the sorghum samples was measured by the vanillin method as modified by Maxson \& Rooney (1972). The test sample is extracted at room temperature with methanol containing Io $\mathrm{ml}$ concentrated hydrochloric acid/l, and on addition of vanillin reagent to this extract a pink colour develops the intensity of which is related to the tannin content. If the content of $\mathrm{HCl}$ in the methanol was increased to $20 \mathrm{ml} / \mathrm{l}$ and the extraction carried out in tightly-stoppered bottles at $48^{\circ}$, then a pink colour with an absorption maximum at about $535 \mathrm{~nm}$ developed in presence of tannins, without need for the addition of the vanillin reagent. This simpler and more sensitive test also gave a measure of tannins present in the testa of field beans, which were poorly extracted under the conditions specified by Maxson \& Rooney (1972). The procedure was as follows. Duplicate I00 $\mathrm{mg}$ samples of the milled seed were weighed into $50 \mathrm{ml}$ bottles, to which were added 
Table 1. Influence of fineness of grinding of the test sample and of different enzymic pretreatments on the available methionine in wheat, barley and rice (Oryza sativa L.) determined by the Streptococcus zymogenes assay

(Values in parentheses represent the 'available' values as proportions of the corresponding 'total')

\begin{tabular}{|c|c|c|c|c|c|}
\hline & & \multicolumn{4}{|c|}{ Methionine ( $\mathrm{g} / \mathrm{kg}$ protein, $\mathrm{N} \times 6.25$ ) } \\
\hline & & \multicolumn{3}{|c|}{ Available } & \multirow[t]{2}{*}{ Total } \\
\hline Test sample & $\begin{array}{c}\text { Digest ... } \\
\text { Fineness* }\end{array}$ & Papain & Pepsin & Pronase & \\
\hline Wheat & $\begin{array}{l}40 \\
80\end{array}$ & $\begin{array}{l}13.8(0.84) \\
14.8(0.90)\end{array}$ & $\begin{array}{l}14.6(0.89) \\
14.8(0.90)\end{array}$ & $\begin{array}{l}15.6(0.95) \\
15.3(0.93)\end{array}$ & $16 \cdot 4$ \\
\hline Barley & $\begin{array}{l}40 \\
80\end{array}$ & $\begin{array}{l}\text { I } 2.9(0.72) \\
\text { I } 3.9(0.78)\end{array}$ & $\begin{array}{l}\text { I } 4.3(0.80) \\
\text { I } 6.9(0.94)\end{array}$ & $\begin{array}{l}16.9(0.94) \\
16.6(0.93)\end{array}$ & 17.9 \\
\hline Rice & $\begin{array}{l}40 \\
80\end{array}$ & $\begin{array}{l}19.9(0.80) \\
21.3(0.86)\end{array}$ & $\begin{array}{l}21.7(0.87) \\
22.9(0.92)\end{array}$ & $\begin{array}{l}2 \mathrm{I} \cdot 7(0.87) \\
24.9(1 \cdot 00)\end{array}$ & 24.9 \\
\hline
\end{tabular}

* The grain was milled to pass a 40 mesh screen. A sample of this coarse-ground material was then ballmilled to pass 80 mesh.

$25 \mathrm{ml}$ methanol containing $20 \mathrm{ml} \mathrm{HCl} / 1$. The bottles were tightly closed with screw-caps fitted with rubber liners that had been lubricated with silicone grease, incubated at $48^{\circ}$ for $\mathrm{I} 6 \mathrm{~h}$ in an 'end-over-end' shaker, and filtered. The absorbance of the filtrate at $535 \mathrm{~nm}$, measured in a $10 \mathrm{~mm}$ cell against the acidified methanol, was designated the 'tannins index'.

\section{RESULTS AND DISCUSSION}

Experiments with rice. In preliminary tests the nine samples of rice were assayed for available methionine, after predigestion with papain but without further ball-milling. The results were compared with those for total methionine and with values for true digestibility of the protein as measured with rats (see Table 2).

The microbiological assay results indicated availabilities of methionine in the range $0.62-0.73 v .0 .9 \mathrm{I}-\mathrm{I} \cdot 00$ digestibility of $\mathrm{N}$ found by Eggum \& Juljano (I973) in rat assays of the same materials. For two of the samples, IR8a and BPI 76-I, the availability of the amino acids had been determined with rats by a faecal analysis procedure and found to be uniformly high and similar to that of the $\mathrm{N}$. There was thus a marked discrepancy between the rat and the microbiological assay results. The rat assay is not infallible as an indicator of protein nutritional quality in other animal species, and it might be that the digestibility of rice protein is lower in humans than in rats. Thus, Clark et al. (1971) reported 0.77-0.78 apparent digestibility of rice protein in human adults, and Miyamoto et al. (196I) reported availabilities of $0.64-0.89$ for seven of the essential amino acids. However, for the purpose of the present study we have assumed that the rat assay values are correct and that the microbiological assay results were too low.

Two factors in the microbiological assay that might strongly influence the results are the fineness of grinding of the test sample and the choice of enzyme used for the predigestion. The endosperm protein of rice is present mainly as discrete $\mathrm{I}-4 \mu \mathrm{m}$ particles in the interstices between the compound starch granules, and in a coarse flour many of these particles might be inaccessible to the digesting enzyme. And the protein is especially rich in glutelins, which are poorly soluble except at high $\mathrm{pH}$ and are better digested by pronase or other alkaline protease (B. O. Juliano, personal communication).

Table $\mathrm{l}$ shows the effects of finer milling, and of pretreatment with different enzymes, on 
Table 2. Total and available methionine in rice (Oryza sativa $L$.) flours, and true digestibility of the nitrogen

Methionine ( $\mathrm{g} / \mathrm{kg}$ protein, $\mathrm{N} \times 6 \cdot 25$ )

\begin{tabular}{|c|c|c|c|c|c|c|c|}
\hline \multirow[b]{2}{*}{ Test material } & \multirow{2}{*}{$\underset{(\mathrm{g} / \mathrm{kg})}{\mathrm{N}}$} & \multicolumn{2}{|c|}{ Total } & \multicolumn{2}{|c|}{ Available } & \multirow{2}{*}{$\frac{\text { Available 2 }}{\text { Total I }}$} & \multirow{2}{*}{2 Digesti- } \\
\hline & & $I^{*}$ & $2 \dagger$ & $1 \ddagger$ & $2 \S$ & & \\
\hline \multicolumn{8}{|l|}{ Milled rice: } \\
\hline Intan & $9 \cdot 55$ & $32 \cdot 8$ & $26 \cdot 9$ & $21 \cdot 3$ & $30 \cdot 3$ & 0.92 & $I \cdot 001$ \\
\hline IR8a & $12 \cdot 30$ & $28 \cdot 8$ & 25.8 & 17.4 & $26 \cdot 6$ & 0.92 & 0.962 \\
\hline IR8b & $16 \cdot 32$ & $23 \cdot 2$ & $22 \cdot 2$ & 14.4 & 23.4 & I.OI & 0.954 \\
\hline IR22a & 12.61 & $22 \cdot 0$ & 27.0 & $19 \cdot 2$ & 28.9 & I.3I & - \\
\hline IR22b & 16.00 & 23.4 & $24 \cdot 7$ & $17 \cdot 0$ & $25 \cdot 7$ & $1 \cdot 10$ & 0.985 \\
\hline IR $480-5-9$ & 18.88 & 25.4 & 25.5 & 16.5 & $24 \cdot 7$ & 0.97 & 0.945 \\
\hline IRII03 & 18.56 & $24 \cdot 5$ & $23 \cdot 9$ & 15.9 & 24.8 & 1.01 & 0.959 \\
\hline BPI $_{176-1}$ & $24 \cdot 32$ & $17 \cdot \mathrm{I}$ & $16 \cdot 1$ & $13 \cdot 3$ & 18.0 & I.05 & 0.944 \\
\hline \multicolumn{8}{|l|}{ Brown rice: } \\
\hline IR $480-5-9$ & I7.44 & $26 \cdot 0$ & $24 \cdot 8$ & 14.0 & $25 \cdot 2$ & 0.97 & 0.908 \\
\hline \\
\hline$(P=0.05)$ & - & 一 & 1.8 & - & I.O & 一 & - \\
\hline
\end{tabular}

LSD, least significant difference.

* From Bressani et al. (1971). The samples were prepared for analysis by the standard hydrolysis procedure without performic oxidation, and analysed by column chromatography.

+ Measured by microbiological assay with Strep. zymogenes.

$\$$ Papain predigestion; samples milled to pass 60 mesh.

$\S$ Pronase predigestion; samples milled to pass 80 mesh.

|| From Eggum \& Juliano (1973).

results obtained for available methionine in samples of wheat, barley and rice. Values for total methionine are given for comparison, and also the 'available' values as a proportion of the corresponding 'totals'. With all three cereals, results obtained with pronase were higher than with papain, though the differences were small and sometimes marginal. The pepsin results tended to be intermediate. Finer grinding of the test samples gave generally higher results, though again the increase if any was small. For further tests it was decided arbitrarily to adopt pronase digestion and, whenever possible, to ball-mill the samples to pass an 80 mesh sieve. Table 2 shows results obtained in this way for available methionine in the nine samples of rice flour, and the results of the preliminary test using papain for comparison.

The higher values for available methionine obtained using the pronase pretreatment are means of four independent assays. The coefficient of variation (based on the 'rice $\times$ assay' interaction mean square in the analysis of variance) was 0.028 and the least significant difference (LSD) $(P=0.05)$ was $1 \cdot 0$. Comparing these values with the 'total' values from chemical assays, the availability of methionine appears to be uniformly high. The 'total' value for IR22a is suspiciously low and probably accounts for the high value (I.3I) for available: total. If we ignore this value then the mean value is $\mathrm{I} \cdot \mathrm{O}$. This is no doubt fortuitous, but there is clearly no indication in these results that the methionine was less than completely available in all the samples. The high availabilities are consistent with the high values for true digestibility of the N reported by Eggum \& Juliano (1973).

Values for available methionine (pronase digestion) were approximately $10 \%$ greater than the corresponding Strep. zymogenes 'total' values, which were probably in error, being uncorrected for any loss of methionine during the acid-hydrolysis. A possible alternative explanation is that the 'total' values were correct and the 'available' values too high. Peptides may stimulate bacterial growth, and so the response to an essential amino acid as present in a di- or tripeptide might be greater than that to an equivalent amount of the free 


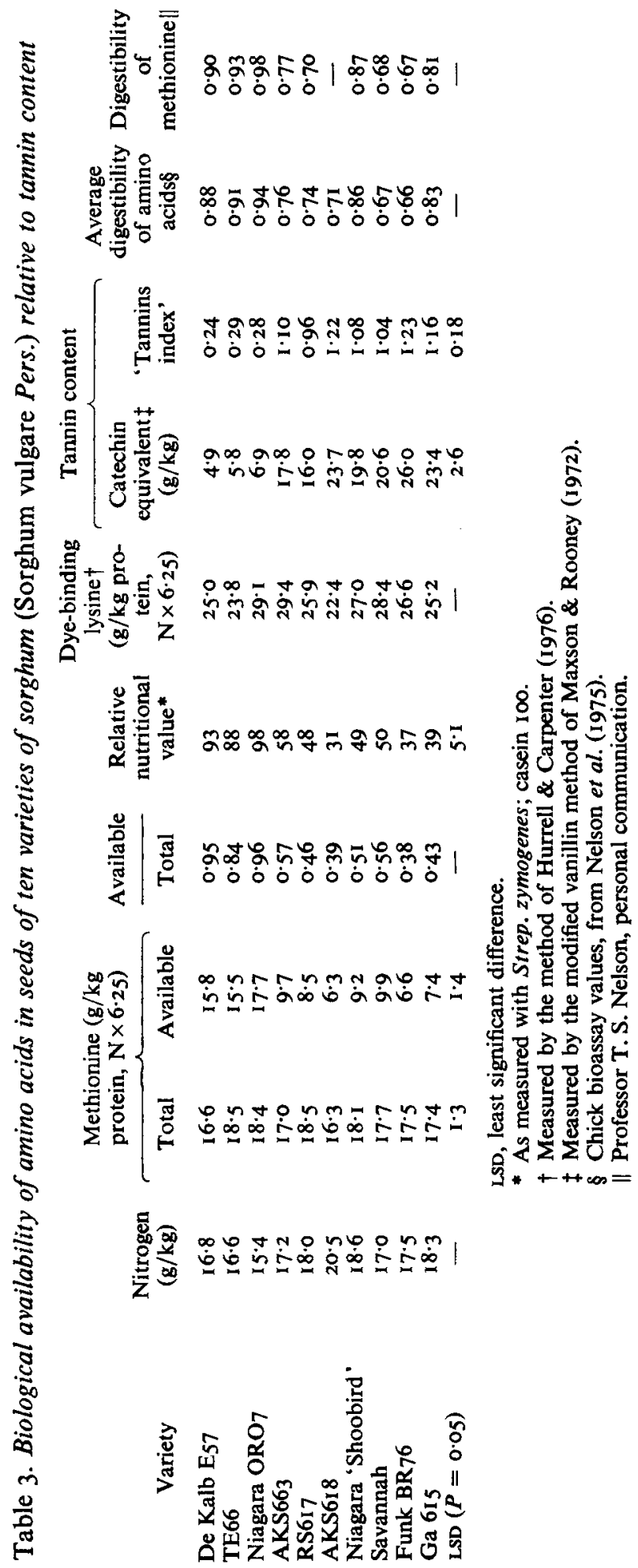




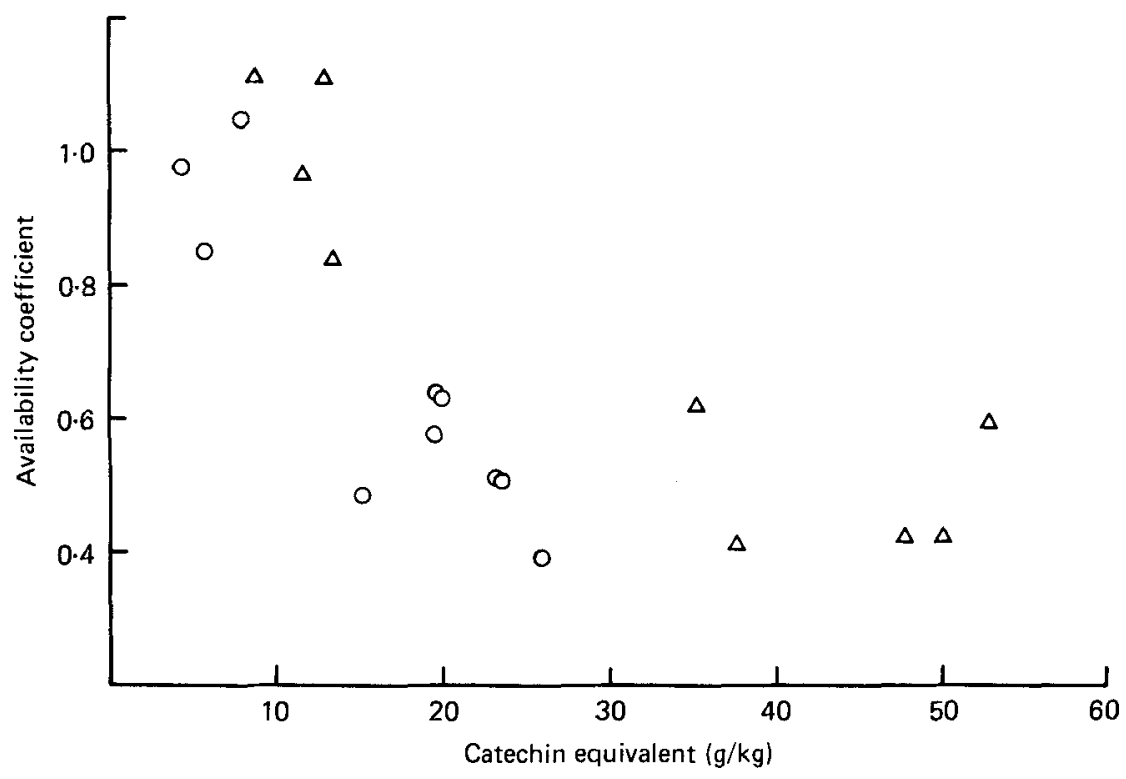

Fig. I. Relationship between availability of methionine and tannin content in grain of the ten varieties of sorghum (Sorghum vulgare Pers.) listed in Table $3(O)$ and nine additional varieties $(\triangle)$.

amino acid. To test this, glycyl-L-methionine and L-methionyl-L-methionine were examined as sources of methionine for Strep. zymogenes under the test conditions used in the assays. Solutions of the two compounds were made up to contain the equivalent of $10 \mu \mathrm{g}$ methionine $/ \mathrm{ml}$ and assayed for methionine activity against a 'standard' of L-methionine. Growth was measured turbidimetrically after incubation of the test cultures for 5, I 4 and $46 \mathrm{~h}$. At 14 and $46 \mathrm{~h}$ the response to the peptides was the same as that to an equivalent concentration of $\mathrm{L}$-methionine, and there was no non-linearity in the assays. At $5 \mathrm{~h}$ both peptides were marginally less active than L-methionine. This evidence against peptide stimulation in the assays is of course not conclusive; it is possible that other methionyl peptides might have behaved differently, or that the relative response to peptide-bound and free methionine might be influenced by unrecognized variables in the assay procedure. As a check on this and on between-assay variation in results, it would be useful to include a reference sample in all the assays as a secondary standard. We did not do this however.

Experiments with sorghum. Results for ten varieties of sorghum are set out in Table 3.

The values for total methionine are means of two independent assays, in one of which were included tests for recovery of L-methionine added to the samples before hydrolysis. The recoveries ranged from $9 \mathrm{I}-107 \%$, but the differences were judged from experience to be attributable to measurement error and the mean recovery ( $\mathrm{IOI} \%$ ) was used in correcting the results. The LSD between-samples was $\mathrm{I} \cdot 3(P=0.05)$, and such small differences as were found were not related to the much wider differences in protein nutritional quality evident in the RNV ratings, which ranged from 3 I-98 (LSD $5 \cdot I$ ). The same was true for the dye-binding lysine values, which for these materials were clearly a fair measure of the total lysine present; they gave no pointer to the differences in digestibility of lysine that are implicit in the chick assay results.

Chick assay values for digestibility of methionine were similar to those for average digestibility of amino acids, which in turn were correlated $(r-0.82 ; P<0.01)$ with tannin content (Nelson et al. 1975). The chick assay procedure employed has been reported as 
Table 4. Availability of methionine and relative nutritional value $(R N V)$ of white-and colouredflowered varieties of field beans (Vicia faba $L$.), in relation to tannin content

\begin{tabular}{|c|c|c|c|c|c|c|}
\hline \multirow[b]{2}{*}{ Variety } & \multicolumn{2}{|c|}{$\begin{array}{l}\text { Methionine }(\mathrm{g} / \mathrm{kg} \\
\text { protein, } N \times 6.25)\end{array}$} & \multirow{2}{*}{$\frac{\text { Available }}{\text { Total }}$} & \multirow[b]{2}{*}{ RNV* } & \multirow{2}{*}{$\begin{array}{c}\text { Dye-binding } \\
\text { lysine } \dagger \\
(\mathrm{g} / \mathrm{kg} \text { pro- } \\
\text { tein, } \\
\mathrm{N} \times 6.25)\end{array}$} & \multirow{2}{*}{$\begin{array}{l}\text { 'Tannins } \\
\text { index' }\end{array}$} \\
\hline & Total & Available & & & & \\
\hline \multicolumn{7}{|l|}{ White-flowered: } \\
\hline Threefold & $8 \cdot 56$ & $6 \cdot 70$ & 0.783 & 66 & 63.0 & 0.024 \\
\hline Compacta & 8.69 & $6 \cdot 45$ & 0.742 & 64 & $66 \cdot 2$ & 0.014 \\
\hline Bianco & $8 \cdot 52$ & 6.90 & 0.810 & 68 & $71 \cdot 2$ & 0.012 \\
\hline Staygreen & $8 \cdot 71$ & $7 \cdot 20$ & 0.827 & $7 \mathrm{I}$ & $64 \cdot 5$ & 0.012 \\
\hline Snow-white & $8 \cdot 81$ & $7 \cdot 00$ & 0.795 & 67 & 70.5 & 0.016 \\
\hline Feligreen & $8 \cdot 56$ & $6 \cdot 85$ & 0.801 & 67 & $68 \cdot 3$ & 0.016 \\
\hline Beryl & $9 \cdot 37$ & $7 \cdot 35$ & 0.785 & 69 & $7 x \cdot 8$ & 0.016 \\
\hline Fidrim & $8 \cdot 34$ & 6.45 & 0.773 & 67 & $68 \cdot 9$ & 0.008 \\
\hline $\mathrm{TW}_{2} \times 73 / \mathrm{I}-2$ & $8 \cdot 27$ & 5.95 & 0.720 & 58 & $69 \cdot 3$ & 0 \\
\hline TW $5 \times 610 / 1-3$ & $7 \cdot 86$ & 6.40 & 0.815 & 62 & 65.5 & 0.012 \\
\hline $76 \mathrm{TW}$ & $8 \cdot 77$ & $7 \cdot 50$ & 0.855 & 67 & $72 \cdot 2$ & 0.050 \\
\hline Mean & $8 \cdot 59$ & $6 \cdot 80$ & 0.791 & $66 \cdot 0$ & $68 \cdot 3$ & 0.016 \\
\hline SD & 0.38 & 0.46 & 0.038 & $3 \cdot 5$ & $3 \cdot 1$ & 0.013 \\
\hline \multicolumn{7}{|l|}{ Coloured-flowered: } \\
\hline Blaze & $8 \cdot 77$ & $5 \cdot 80$ & 0.662 & 57 & $64 \cdot 5$ & 0.835 \\
\hline Bead & $8 \cdot 99$ & $5 \cdot 85$ & 0.651 & 65 & $67 \cdot 3$ & 0.835 \\
\hline Throws & 8.99 & 5.85 & $0.65 \mathrm{I}$ & 57 & $68 \cdot 1$ & 0.908 \\
\hline Bulldog & $9 \cdot 49$ & $6 \cdot 30$ & 0.664 & 63 & $70 \cdot 3$ & 0.710 \\
\hline Compacta, brown & 9.55 & $6 \cdot 55$ & 0.686 & 64 & $71 \cdot 8$ & 0.710 \\
\hline Felix & $9 \cdot 34$ & 6.85 & 0.734 & 68 & $74 \cdot 6$ & 0.688 \\
\hline Minden & $9 \cdot 24$ & $6 \cdot 55$ & 0.709 & 64 & $70 \cdot 7$ & 0.700 \\
\hline Red epicure & $9 \cdot 31$ & $7 \cdot 25$ & 0.779 & 65 & 69.9 & 0.520 \\
\hline Imperial green & $9 \cdot 87$ & $6 \cdot 45$ & 0.654 & 62 & $65 \cdot 4$ & 0.960 \\
\hline Line 78 & $8 \cdot 59$ & 5.95 & 0.693 & 59 & $62 \cdot 8$ & 0.710 \\
\hline Beagle & $8 \cdot 56$ & $5 \cdot 60$ & 0.654 & 57 & $65 \cdot 0$ & 0.980 \\
\hline Mean & $9 \cdot 15$ & $6 \cdot 27$ & 0.685 & $61 \cdot 9$ & $68 \cdot 2$ & 0.778 \\
\hline SD & 0.41 & 0.51 & $0.04 \mathrm{I}$ & $3 \cdot 8$ & 3.6 & 0.139 \\
\hline $\operatorname{LSD}(P=0.05)$ & - & 0.96 & - & - & 一 & - \\
\hline
\end{tabular}

LSD, least significant difference.

* As measured with Strep. zymogenes; casein 100.

$\dagger$ Measured by the method of Hurrell \& Carpenter (1976).

giving unduly high results (Elwell \& Soares, 1974) and certainly a wider spread of values $(6.3-17.7 \mathrm{~g} / \mathrm{kg}$ protein $(\mathrm{N} \times 6.25))$ was obtained in the microbiological assays for available methionine. These results are means of three independent determinations, in which the within-sample variation was $14.7 \%$ and the LSD $(P=0.05)$ between-samples was $\mathrm{I} \cdot 4$.

The availability coefficients (available: total methionine) ranged from 0.38 to 0.96 and were highly correlated with tannin content expressed as catechin equivalent $(r-0.95$; $P<0.001)$ or as tannins index $(r-0.97 ; P<0.001)$. This high correlation was impaired when results for a further nine sorghums were included. Fig. I shows availability coefficient $v$. tannin content for nineteen sorghums. The ten varieties listed in Table 3 are represented separately from the nine additional varieties, and it is clear that though high tannin content is associated with low availability of methionine, the relationship is in fact not a simple linear one.

The two methods employed for assessing tannin content, the 'modified vanillin' and the simpler 'tannins index', graded the test samples in much the same order and the two sets of ratings were closely correlated $(r 0.98 ; P<0.001)$. 


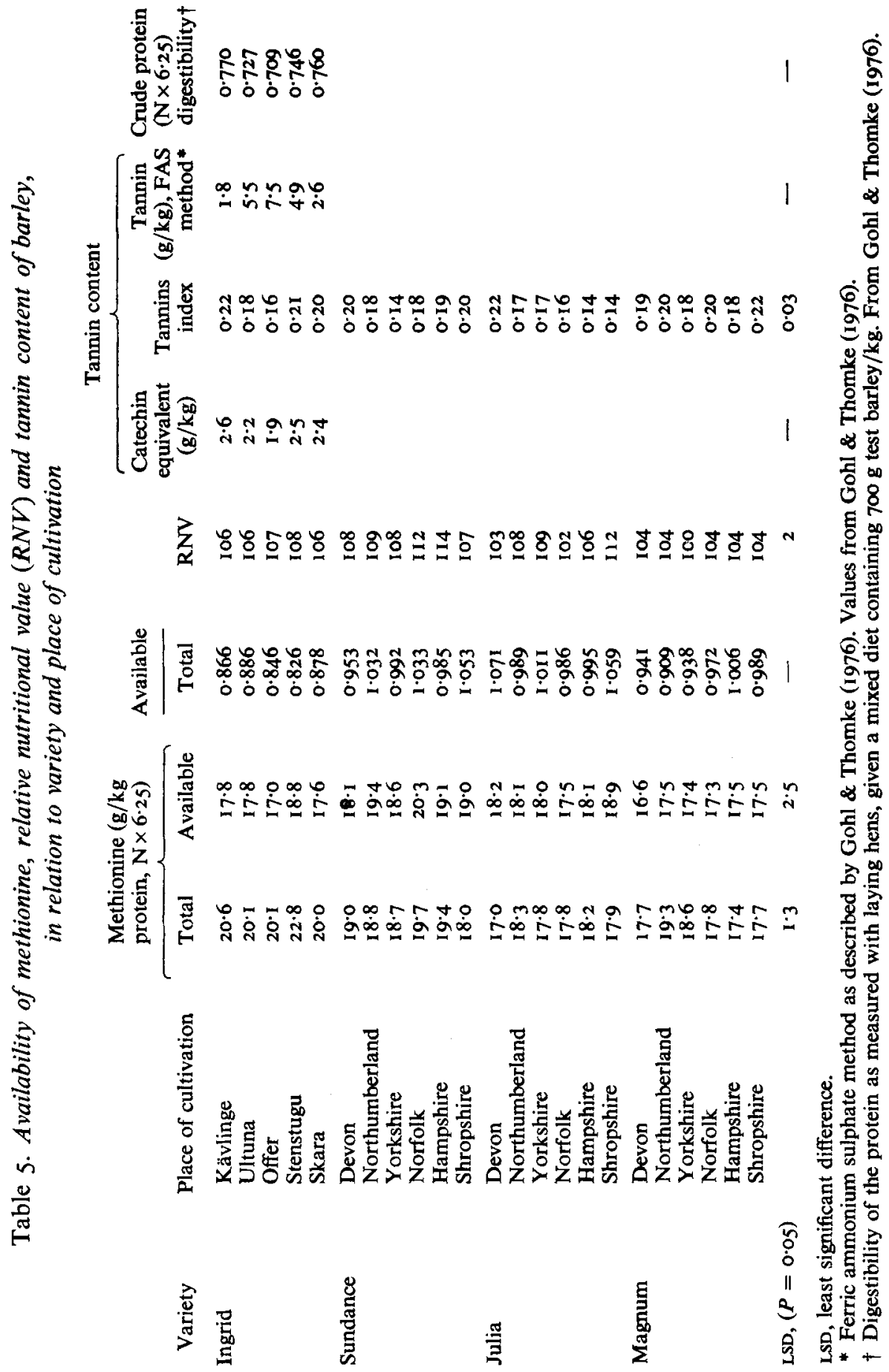


Experiments with field beans. Table 4 shows results obtained for ground whole seed of twenty-two varieties of field beans.

The results for total methionine are corrected for average recovery of added L-methionine, but the recovery values were lower and more variable than with sorghum, averaging only $60.1 \%$. The variation in the individual 'corrected' results should therefore be discounted. The average values for the white-flowered and coloured-flowered groups do however provide a basis for comparison with the corresponding 'available' values.

Analysis of variance in the assay values showed that, as a group, the white-flowered varieties contained more available methionine per unit weight of protein than the colouredflowered varieties $(P<0.001)$. Mean $( \pm S D)$ values for the two groups were $6.8 \pm 0.46$ and $6.27 \pm 0.5 \mathrm{I}$, and the corresponding mean coefficients of availability were $0.79 \mathrm{I} \pm 0.038$ and $0.685 \pm 0.04 \mathrm{I}$. Mean RNV ratings also were marginally higher for the white-flowered varieties, $66 \cdot 0 \pm 3.5 v \cdot 6 \mathrm{I} \cdot 9 \pm 3 \cdot 8$, but dye-binding lysine values were much the same for white- and coloured-flowered groups, $68 \cdot 3 \pm 3 \cdot I$ and $68 \cdot 2 \pm 3 \cdot 6$ respectively.

Beans of the white-flowered varieties contained no tannins measurable by the 'tannins index' procedure, whereas those of the coloured-flowered varieties contained high amounts. Separate analysis of testa and cotyledons from the coloured-flowered variety Beagle showed that tannin was present only in the testa. This was to be expected from the work of Bond (I976) who, in a comprehensive survey, showed that the seed coat of all the white-flowered varieties examined was free of tannin. Whole grain of these varieties averaged $4.7 \%$ higher in in vitro digestibility of the dry matter than grain of coloured-flowered varieties. The difference was largely attributable to a much greater difference in digestibility of the testa, 0.56 v. 0.17 .

We found differences in tannin content within the coloured-flowered group, and the values were negatively correlated with those for available methionine $(r-0.75 ; P<0.01)$ and availability coefficient $(r-0.86 ; P<0.001)$. Griffiths \& Jones (1977) similarly found considerable variation in tannin content within coloured-flowered varieties, which was highly correlated with the digestibility of the testa by cellulase. They concluded that depression of cellulase activity by the bean tannins might be of particular importance in relation to the usefulness of whole-bean meal in diets for ruminants.

Experiments with barley. Results for twenty-three of the barleys are set out in Table 5 .

Values for total methionine are means from two independent assays, corrected for the mean recovery of methionine $(82 \%)$. The $\operatorname{LSD}(P=0.05)$ between samples was $\mathrm{I} \cdot 3$. Clearly there was over-all no wide variation in methionine content between varieties, though variety Ingrid, grown in Sweden in 1976 , was marginally richer than Sundance, Julia and Magnum, grown in England during the cool and dull season of 1977 .

The values for available methionine again showed little difference between the varieties though the average for variety Sundance was marginally higher than those for the others. When analytical values for another ten barley varieties (p. 242) were included, then for total methionine the mean $( \pm \mathrm{SD})$ value was $20.3 \pm \mathrm{I} \cdot 6 \mathrm{~g} / \mathrm{kg}$ protein $(\mathrm{N} \times 6.25)$, and for available methionine $17.9 \pm \mathrm{I} \cdot 3 \mathrm{~g} / \mathrm{kg}$ giving an over-all average availability coefficient of 0.88 . The average availability coefficient for the barleys grown in Sweden was $0.851 \pm 0.042$ and for those grown in England it was $0.995 \pm 0.044$, but the difference was probably related to seasonal, geographical or other environmental factors rather than to any intrinsic differences in the barley varieties. It was clearly not associated with any difference in tannin content. When compared with the values for sorghums (Table 3 ) and field beans (Table 4), the tannins index ratings for the barleys were uniformly low (average $0.2 \mathrm{I} \pm 0.034$ ) and showed no consistent variation with 'variety' or 'place of cultivation'. Tannin was also measured as catechin equivalent (Maxson \& Rooney, 1972) in the fifteen barleys grown in Sweden, and again the values were comparatively low (average $2.9 \pm 0.54 \mathrm{~g} / \mathrm{kg}$ ), and highly correlated 
with those for tannins index $(r 0.94 ; P<0.00 \mathrm{I})$ despite the small differences between samples.

In marked contrast with these findings, Gohl \& Thomke (I976) reported wide variation in the tannin content of the five samples of barley variety Ingrid, as measured by the reaction with ferric ammonium sulphate. Their values for tannin content $(\mathrm{g} / \mathrm{kg})$ ranged from $\mathrm{I} \cdot 8$ for 'Kävlinge' to 7.5 for 'Offer' (Table 5), and these wider differences were reflected in corresponding differences in crude protein $(\mathrm{N} \times 6.25)$ digestibility as measured with laying hens given mixed diets in which the barleys supplied about half the protein. But in tests with broiler chickens we found no difference between 'Kävlinge' and 'Offer' in true protein digestibility, as measured by the ileal analysis procedure of Varnish \& Carpenter (1975). Possible reasons for these contradictory results will be discussed in a later paper (Ford \& Hewitt, unpublished results).

\section{Conclusions}

The present findings illustrate a need for caution when assessing the nutritional quality of grain proteins from their amino acid composition. There have been several reports of low biological availability of amino acids in cereals, though some of the evidence is not altogether convincing and it may be that the importance of the nutritional problem has often been exaggerated (cf. de Muelenaere et al. 1967). But there is no doubt that the presence of tannins in some food grains may impair the nutritional quality, and we need to introduce some element of biological specificity into the design of in vitro methods for evaluating such materials. With the sorghums (Table 3) the differences in nutritional quality of the grain protein were determined much more by the digestibility than by the amino acid composition, and the small differences in total methionine and dye-binding lysine were irrelevant. There were much larger differences in available methionine and the values were closely correlated with those for tannins content, but less precisely $(r 0.8 \mathrm{I} ; P<0.0 \mathrm{I})$ with chick values for digestible methionine obtained by the faecal analysis procedure (Nelson et al. 1975). Experience from further comparative tests on low- and high-tannin sorghums, using microbiological, chick (ileal digestibility) and rat (net protein utilization) assays showed that high tannin content was invariably associated with low availability of methionine, as measured microbiologically, and low true digestibility of protein in the chick and rat tests (Ford \& Hewitt, unpublished).

The modified assay procedure here described is simple as microbiological assays go, and reasonably precise. It must be understood that the values for available methionine have no absolute validity, and they must be checked and standardized in comparative tests with animals and, ideally, with the species for which the proteins are intended. This is equally true for all in vitro procedures for protein evaluation. But used intelligently they can be of great help to the nutritionist in extending the scope of animal tests.

The authors are grateful to Mrs Dinah Bishop for technical assistance, and to the following persons who kindly provided the test samples for investigation: Dr J. Axtell, Dr D. Bond, Dr Eva Holmberg, Dr B. O. Juliano, Mr G. C. Mann, Professor T. S. Nelson and Dr S. Thomke.

\section{REFERENCES}

Bond, D. A. (1976). J. agric. Sci., Camb. 86, $56 \mathrm{I}$.

Boyne, A. W., Ford, J. E., Hewitt, D. \& Shrimpton, D. H. (I975). Br. J. Nutr. 34, I 53.

Bressani, R., Elias, L. G. \& Juliano, B. O. (197I). J. agric. Fd Chem. 19, 1028.

Carpenter, K. J. \& Woodham, A. A. (I974). Br. J. Nutr. 32, 647.

Clark, H. E., Howe, J. M. \& Lee, C. J. (I97I). Am. J. clin. Nutr. 24, 324.

de Muelenaere, H. J. H., Chen, M. L. \& Harper, A. E. (1967). J. agric. Fd Chem. x5, 310.

Eggum, B. O. \& Juliano, B. O. (1973). J. Sci. Fd Agric. 24, 921. 
Elwell, D. \& Soares, J. H. (1974). Poult. Sci. 54, 78.

Ford, J. E. (1962). Br. J. Nutr. 16, 409.

Ford, J. E. (I964). Br. J. Nutr. 18, 449.

Ford, J. E. \& Salter, D. N. (I966). Br. J. Nutr. 20, 843.

Gohl, B. \& Thomke, S. (1976). Poult. Sci. 55, 2369.

Griffiths, D. W. \& Jones, D. I. H. (1977). J. Sci. Fd Agric. 28, 983.

Hegsted, D. M. \& Juliano, B. O. (1974). J. Nutr. ro4, 772.

Hurrell, R. F. \& Carpenter, K. J. (I975). Br. J. Nutr. 33, Ior.

Hurrell, R. F. \& Carpenter, K. J. (1976). Proc. Nutr. Soc. 35, 23A.

Martin-Tanguy, J., Guillaume, J. \& Kossa, A. (1977). J. Sci. Fd Agric. 28, 757.

Maxson, E. D. \& Rooney, L. W. (1972). Cereal Chem. 49, 7 I 9.

Miller, E. L., Carpenter, K. J., Morgan, C. B. \& Boyne, A. W. (1965). Br. J. Nutr. 19, 249.

Miyamoto, T., Shinkai, T., Ikehata, H. \& Murata, K. (1961). Rep. Sci, Living, Osaka City Univ. 9, 7.

Nelson, T. S., Stephenson, E. L., Burgos, A., Floyd, J. \& York, J. O. (I975). Poult. Sci. 54, 1620.

Varnish, S. A. \& Carpenter, K. J. (1975). Br. J. Nutr. 34, 339. 